By NORMAN N. GILL

\title{
A Municipal Reference Library in Action
}

Mr. Gill, librarian, Municipal Reference Library, Milwaukee Public Library, gave this address to the Milwaukee Chapter of the Special Libraries Association on Nov. I7, 1942 .

$\mathrm{T}$ HIS YEAR marks the thirty-fifth anniversary of the establishment of the local Municipal Reference Library. Milwaukee was the second city in the country to set up this type of institution. Through the years the library, a department of the public library system but located in the city hall, has grown to a reference and research division rendering service to the mayor and common council, city officials and employees, civic organizations, and the general public. This year's budget is thirteen thousand dollars, with a staff including the librarian, a cataloger, a reference assistant, and two juniors. The ordinance reorganizing the municipal reference department in I9I I provided that the librarian "shall be an expert in political science, political economy, and statistics." All employees are under civil service. The legal requirement for special training by the librarian makes it clear that the city fathers of I9II, and, I may add, of today, expected a good deal more of the reference agency than merely the custodianship of a static storehouse of books.

The ordinance establishing the library makes it mandatory for the institution "to collect and compare the laws of other states and cities; to report upon the laws and ordinances regarding any subject, upon request of the mayor, any committee or member of the common council, or any department head; to collect all available information relative to any matter which may be the subject of proposed legislation by the common council; to preserve and collate information obtained, indexed, and arranged for the convenience and use of city officials and the general public." This quotation from the law is itself a good picture of the type of collection and the nature of the activities of the library.

In addition, the library is required to compile and edit each year the annual consolidated report of the activities of the various departments, bureaus, boards, and commissions which are under the control of the common council; to keep up to date and properly arranged and indexed the city code of ordinances; to prepare and keep on file the master census tract map of the city; to be in charge of the distribution of census tract data to interested organizations and individuals; to publish, at the direction of the common council, the official rules and regulations of the various departments and bureaus. The librarian is required to attend all meetings of the common council and all meetings of its standing committees. 
The library contains about forty-eight thousand books and pamphlets, including standard reference works on local government and thousands of clippings from thirteen newspapers and three hundred periodicals. All new materials, including monthly periodicals, reports, and special studies, and city, state, and federal government documents, are routed to individuals upon request or in accordance with the special interests of the person concerned. A monthly bulletin is prepared and distributed to five hundred city and county officials, containing annotated lists of recent accessions, guest book reviews written by city employees, special articles and news notes on current items of city government. The routing service last year included the circulation of over 4500 pamphlets and books.

\section{Reference Collection}

The reference collection includes an extensive body of archival materials, such as the published and unpublished reports of the city, school board, county, and the state, as well as the minutes of various boards and commissions, departmental audits, proceedings of the common council, and a complete file of state and session laws. During the legislative session all bills introduced in both houses of the state legislature are kept on file for the use of the departments when such bills are called to their attention by the city's legislative counsel or by the librarian. Numerous queries and questionnaires about the city's methods and procedure are referred by the mayor and department heads to the library for reply. The library acts as the agency for the exchange of city documents and departmental reports.

As the storehouse of official documents, the depository of information to the pub- lic, and in the role of a neutral coordinating agency, the library has been entrusted for the past twenty-one years with the task of preparing the consolidated annual report of city government activities. These reports are used extensively as teaching material in the civics and social science classes of our local schools.

\section{Card File}

Another informational service is the development of a card file of both the city code and charter in an elaborate index, which is kept up to date. By ordinance the library is required to assign code numbers to new sections, to note all repeals of sections, and to perform related technical duties. The ordinance file and index and the subject file of ordinances of other cities are among the most frequently used library services.

While the library's primary role is that of an information agency for city officials, a recent check showed that four out of every ten reference questions come from individual citizens, civic bodies, taxpayer groups, improvement associations, newspapers, teachers, and students. Requests from these sources range from simple yes and no questions to technical surveys requiring considerable time and thought. These requests serve. as excellent media for spreading the library's storehouse of information about the best practices in local government in strategic "thought centers" around the community.

What may be regarded as the most important work of the library, to which the municipal reference librarian devotes most of his time, may be described as "research -secretarial-consulting services." The research may take the form of a bibliography on air raid shelters or the preparation of the background data for an 
important message to the common council. The secretarial work may range from the translation of a letter written in a foreign language to acting as executive secretary of an important committee of city officials over a period of several years. The consulting service may take the form of a confidential discussion with an elective official regarding the advisability of a certain course of action.

\section{Research Work}

Illustrations of major research work are the surveys of the procedures followed by other cities in preparing long-range permanent improvement programs; the organization and financial support of art institutes in various cities; and recent trends in salary and wage scales of public employees in a number of large cities. Each study was prepared in response to an official request, following the development of an important city problem, the awareness that a body of impartial facts drawn from the best experience of other cities would be of value in arriving at a decision in the best interests of the entire community, and the recognition that the library was an agency technically qualified to prepare a thorough and unbiased report. All three reports were put to practical use; they did not accumulate dust on library shelves. About 650 requests were received for copies of these three reports from individuals and agencies in over 150 cities, and the reports were abstracted and appeared in several national periodicals in the respective fields with which they were concerned.

It has been a long-standing tradition for the library to render secretarial services, including the drafting of communications, proclamations, reports, and special documents; the appointment by the mayor or the common council of the librarian as secretary to various committees, involving considerable time in attendance at meetings, reference, research, and reporting work, the preparation of memoranda and agenda, and the drafting of resolutions and ordinances. Following the submission of the report on long-term improvement programs in other cities, the librarian was appointed secretary to the committee of city officials, created by the common council, to develop such a program for Milwaukee. Another illustration is the work of the librarian as secretary to both the policy-formulation and technical bodies representing the five local governments of the Milwaukee city area, which prepared a report on the possibilities of uniform classification and compensation scales for the employees of the city, county, school board, vocational school, and sewage commission. The librarian serves as secretary to the Mayor's Council of Departmental Administration, which includes all major city department and bureau heads and which meets periodically to discuss interdepartmental matters of city administration. The librarian is secretary of the special committees on budget procedures and on licensing methods. The librarian also serves in a confidential secretarial capacity to the mayor's office and to various members of the common council.

\section{Suggestions}

A municipal reference librarian in action can be worth his salary many times over if he does nothing more than make effective suggestions at the right time and place, to the proper persons, regarding vital city problems. Of course, this must be done tactfully and diplomatically, without thought of personal credit or publicity. Avoidance of politics and partisanship is 
part of the operating policy of the library. Whatever publicity does get into the press is always in the form of a summary of a factual report and never a statement of opinions of the librarian.

My own background, training, and interests are largely in the research-secretarial-consulting activities; and I have shaped the library's work accordingly. The term municipal reference "library" is a misnomer, as it gives to many people the idea of simply a storehouse of books. "Department of Municipal Research" or the "Municipal Reference Bureau" might be more accurate titles. Likewise, the term "municipal reference librarian" is misleading. More appropriate titles might be "chief" or "director" of the "department" or "bureau" of "municipal reference" or "municipal research."

A number of the entries in the Community Betterment Contest conducted recently by the Milwaukee Journal and the Milwaukee City Club suggested the establishment of a research bureau as an integral part of the city government. The municipal reference library might well serve as the nucleus around which such a bureau could be created. It has a complete collection of city research materials, a reputation for impartiality and objectivity, a trained staff, an atmosphere of study and investigation, and a tradition of harmonious relations and good cooperation with the executive, legislative, and administrative branches of the city government.

\section{War Information Activities}

Finally, I should like to comment briefly about the library's war information activities. These have been developed as supplementary to the regular activities and not by neglecting the latter. "Good gov- ernment is good defense," and it is likewise true that informational service for good government is also good defense. In recent months special emphasis has been given to the development of a comprehensive collection of materials relating to national and civilian defense, on such topics as organization of local defense councils, air raid shelters, blackout ordinances, staggered hours, camouflage techniques, priorities and rationing orders, fair rent regulations, salvage campaigns, and civilian defense training materials. In the early stages of the local civilian defense work, the library rendered secretarial services to the mayor's civic coordinating council on defense problems, and the librarian is at present on the research committee of the county defense council and statistician to several of the council's committees.

The common council, by resolution, recently instructed the library to prepare a special war code of all official actions taken by the city government relating to the war effort for the duration. News items on civilian defense are prepared for the monthly bulletin of the county defense council. Information as to state and federal developments is supplied regularly to the aldermen in their capacity as chief air raid wardens in their wards, and bibliographies are prepared upon request. The most recent activity has been the preparation, at the request of the executive director of the county defense council, of a set of reading materials to be used for teaching purposes in the air raid warden training evening classes held in the public schools throughout the city. The materials are abstracted from books, periodicals, and pamphlet materials in the library, with the cooperation of the public library's war information center. 